\title{
Implementation of TOPSIS Method in the Selection Process of Scholarship Grantee (Case Study: BAZIS South Jakarta)
}

\author{
Meinarini Catur Utami, Yuni Sugiarti, Ahmad Melani, Yusuf Durachman, A'ang Subiyakto \\ Department of Information System, Syarif Hidayatullah State Islamic University Jakarta \\ J1. Juanda No. 95, Ciputat \\ Tangerang Selatan, Banten, 15412, Indonesia
}

\begin{abstract}
The quantity versus equity is one of the main contextual constraints of the educational world in Indonesia. It is why the scholarship program may one of the chose solutions by many institutions in this country for solving the problem. This case study was conducted to develop the decision support system which can cover the manual process in the sampled institutions using TOPSIS method. As an education support costs assistance, the program is awarded to those who entitled to receive, especially by classification, quality, and competence of the grantee. Referring to the observation study, besides the applicant number, its selection process has also been conducted manually. The result of this study presented the applicant ranks on the weight basis by using seven determined criteria.
\end{abstract}

Keywords- TOPSIS method; applicant selection; scholarship grantee; BAZIS; Indonesia.

\section{INTRODUCTION}

Besides the gaps of quality versus resources and unity versus diversity, the quantity versus equity is also one of main contextual constraints in the educational world in Indonesia [1]. Here, despite the fact that the scholarship program may not solve completely the constraint, it may be a considered solution point, in regard to the contextual dilemma. Thus, it is why the programs have been implemented by many institutions, including the Agency of Amil, Zakah, and Shadaqah (Badan Amil Zakat dan Shadaqah-BAZIS) Jakarta. One of the services is a scholarship program which provides scholarships to students who awarded, but economically disadvantaged. As an education support costs assistance, the program is awarded to those who entitled to receive, especially by classification, quality, and competence of the grantee. Referring to the observation study at the early stage of this research, besides the applicant number, its selection process has also been conducted manually. Along with many submissions from the applicants, more files are accepted by the administration. The applicant data may vulnerable to lose and damage due to improper hands. Thus, it will be difficult to find if the files required someday.

Based on the selection data, it is shown that the average number of applicants during 2012-2015 have been significantly increased in around $5.68 \%$ annually (Fig. 1). The average number applicant accepted was almost $54.13 \%$ of the total registrants. It means that nearly half of the applicants were rejected. The selectors should be more selective for determining the qualified applicant. Furthermore, the selection of scholarship recipients will be having some difficulties due to huge applicant numbers and also limited quota, as well as the various criteria used to make decisions on the acceptance as expected.

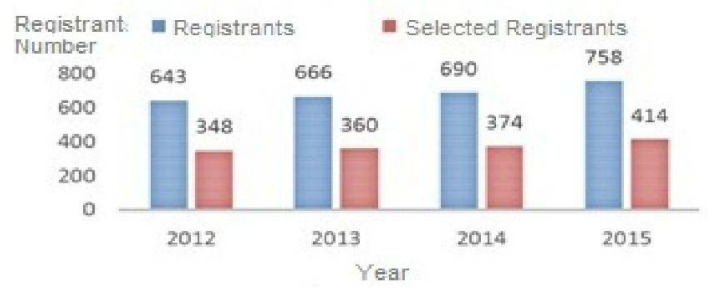

Fig. 1. The Registrant Data 2012-2015

Accordingly, this study was performed, in regard to respond the manual selection process. The aim was to develop the decision support system which can cover the manual process. The objective was to develop the system using the TOPSIS method. The paper is staged within five sections, including the introduction, theoretical framework, research method, results and discussion, and the conclusion sections.

\section{THEORETICAL FRAMEWORK}

The decision is a choosing action or strategy activities of a problem-solving. Its aim is to achieve certain targets or actions to be done. Bonczek, Holsapple and Whinston [2] described its characteristics, e.g., it has a many alternative options, there are obstacles (terms), following a pattern/model behaviour (either structured or unstructured), has many input/variables, risk factors, and speed needed, precision, and accuracy. One of the important components of modern decision science is multiattribute decision making (MADM) [3, 4]. Referring to [3, 4], MADM is described as a decision-making model to evaluate alternatives of sets of attributes or criteria (where each attribute is not interdependent with each other), using the decision matrix of performance rating alternatives, and weight values of the decision maker. It is finally pass through the ordering process to get the best alternative which has been got based on the overall value of the preference given. One of the MADM methods is using a fuzzy technique to order performance by similarity to ideal solution (TOPSIS) $[5,6]$.

TOPSIS firstly introduced by Hwang and Yoon in 1981. The method is implemented based on a concept that the best 
alternative selected is not only the shortest distance from positive ideal solution but also it has the longest distance from negative ideal solution $[5,6]$. The previous studies (e.g., $[5,6]$ ) elucidated that the method has a simple concept and easy to understand, efficient computation, and has the ability to measure the relative performance of the alternatives a decision in the form of a simple mathematical. This method is also useful for the qualitative and quantitative data and relatively easier and faster with a systematic process rather than the other methods [7]. In addition, TOPSIS is also able to show the best and the worst alternative method simultaneously, revealing logic that describes thinking on human selection, visualize the performance measurement of all alternative method on attribute/criteria, and can be easily programmed into the spreadsheet [8]. In general, the TOPSIS procedures follow the following steps [9]:

- Create normalized decision matrix.

- Create a weighted normalized decision matrix.

- Determine the positive ideal solution matrix and the negative ideal solution matrix.

- Determine the distance between the value of each alternative to the ideal solution matrix positive and negative ideal solution matrix.

- Specifies a preference value for each alternative.

TOPSIS requires each alternative $\mathrm{A}_{\mathrm{i}}$, on each criteria normalized $C_{j}$, i.e:

$$
\begin{gathered}
\mathbf{r}_{\mathbf{i j}}=\frac{\mathbf{x}_{\mathbf{i j}}}{\sqrt{\sum_{\mathbf{i}=\mathbf{1}}^{\mathbf{m}} \mathbf{x}_{\mathbf{i j}}^{2}}} \\
\text { for } \mathrm{i}=1,2, \ldots, \mathrm{m} ; \text { and } \mathrm{j}=1,2, \ldots, \mathrm{n} .
\end{gathered}
$$

Positive ideal solution $\left(\mathrm{A}^{+}\right.$and negative ideal solution $\left(\mathrm{A}^{-)}\right.$ can be determined based on normalized weight rating $\left(\mathrm{y}_{\mathrm{ij}}\right)$ as:

$$
\begin{gathered}
\mathbf{y}_{\mathrm{ij}}=\mathbf{w}_{\mathbf{i}} \mathbf{r}_{\mathrm{ij}} ; \\
\text { for } \mathrm{i}=1,2, \ldots, \mathrm{m} ; \mathrm{and}=1,2, \ldots, \mathrm{n} . \\
\mathrm{A}^{+}=\left(\mathrm{y}_{1}^{+}, \mathrm{y}_{2}^{+}, \ldots, \mathrm{y}_{\mathrm{n}}^{+}\right) ; \\
\mathrm{A}^{-}=\left(\mathrm{y}_{1}^{-}, \mathrm{y}_{2}^{-}, \ldots, \mathrm{y}_{\mathrm{n}}^{-}\right) ;
\end{gathered}
$$

for:

$$
\begin{aligned}
& y_{j}^{+}= \begin{cases}\max _{i} y_{i j} ; & \text { ifjis an attribute of benefit } \\
\min _{i} y_{i j} ; & \text { ifjis an attribute of cost }\end{cases} \\
& y_{j}^{-}= \begin{cases}\max _{i} y_{i j} ; \text { ifjis an attribute of benefit } \\
\min _{i} y_{i j} ; \text { ifjis an attribute of } & \text { cost }\end{cases} \\
& j=1,2, \ldots, \mathrm{n} .
\end{aligned}
$$

The distance between the alternative $A_{i}$ with the positive ideal solution is defined as:

$$
\begin{gathered}
D_{i}^{+}=\sqrt{\sum_{j=1}^{n}\left(y_{i j}-y_{i}^{+}\right)^{2}} \\
i=1,2, \ldots, \mathrm{n} .
\end{gathered}
$$

The distance between the alternative $A_{i}$ with the negative ideal solution is defined as:

$$
\begin{gathered}
D_{i}^{-}=\sqrt{\sum_{j=1}^{n}\left(y_{i j}-y_{i}^{-}\right)^{2}} ; \\
i=1,2, \ldots, \mathrm{n} .
\end{gathered}
$$

Preference value for each alternative $\left(\mathrm{V}_{\mathrm{i}}\right)$ is given as:

$$
\begin{aligned}
& V_{i}=\frac{D_{i}^{-}}{D_{i}^{-}+D_{i}^{+}} \\
& \mathrm{i}=1,2, \ldots, \mathrm{n} \text {. }
\end{aligned}
$$

$V_{i}$ greater value indicates that the preferred alternative $A_{i}$.

Similar research related to the TOPSIS method has been carried out, including:

- Saragih, Marbun and Reza [10] studied on the design of decision support system application to determine the scholarship grantee in STMIK Medan Pelita Nusantara. The scholarship grantee decision is done conventionally with a meeting between donor agencies, the committee chairman, and chairman of the study program so that the determination of the scholarship grantee cannot be objective, old and inaccurate. Research is conducted to focus on designing decision support system application through the application of TOPSIS method. The criteria consisted of six criteria, that is GPA, attitude, discipline, tidiness, drug-free, and activities of the organization. Based on applications built, results and information related to the determination of the students as recipients become more objective, rapid, and accurate.

- Wimatsari, Putra and Buana [11] applied on decisionmaking related to selecting of scholarship at University of Udayana, Bali. Selection of scholarship became difficult and long because a lot of applicants and the diversity of the criteria used to determine the type of scholarship as expected. This study used TOPSIS method to determine the type of scholarship that is in accordance with the values of the criteria of each student. The used criteria consisted of four criteria, i.e., GPA, the number of dependents of parents, the use of electrical power, and student activities. The results show that TOPSIS method presents the ranking of the biggest to the smallest value that helps decision makers to determine the appropriate type of scholarship for students.

- In another subject, Srikrishan, Sreenivasulu Reddy and Vani [12] used TOPSIS in the selection of new cars in a market. Selection of the car is crucial for the buyers because many traders were deceiving buyers. In addition to budget problems, the criteria that are considered in the selection of new cars is fuel consume, models, lifestyle and price. The purpose of this study is to make the right decision on choosing the best car for buyers and manufacturers using TOPSIS method. The results of the 
study explained that the proposed TOPSIS method is quite easy to use, and very good for the aggregation process. This method can be applied to rank preferences for the car selection.

\section{RESEARCH METHOD}

Fig. 2 presents the four main phases of the study across the literature study (1), data collection (2), application development using the rapid application development (RAD) $[13,14]$, and the report writing stage (4) at the end of the exploratory study. As it was described by the previous studies [15-17] which indicated utilizations of the prior theoretical and methodological findings, this study has also used the previous findings following its similar topic its self.

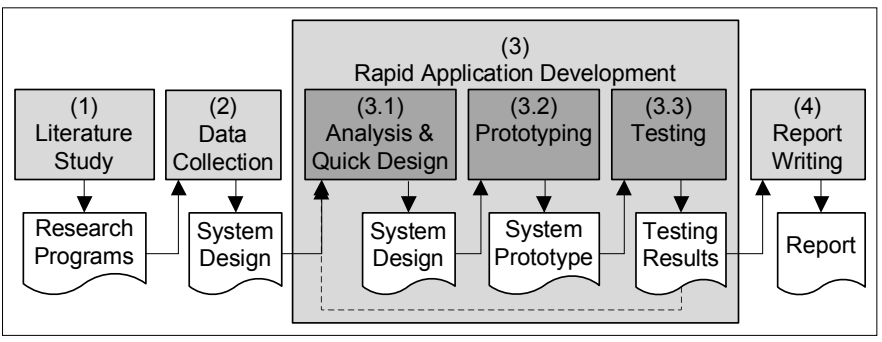

Fig. 2. Procedure of the Study

The data collection stage was performed by the researchers using observation and interview techniques. The observation was done to obtain data needed for research, such as the scholarship application form file, the result of selection of the grantee from 2012 - 2015, and also the assessment criteria made as the reference to the scholarship grantee selection process on BAZIS South Jakarta. On the other technique, the interviews involved one supervisor and two administration staffs of the sampled institutions as its participants. From result of the interview, it can be seen a general idea about the company profile, the scholarship characteristics of BAZIS South Jakarta, and the parts that are involved in it, as well as the technical issues of the scholarship management such as workflow in which started from the administrative until the selection process, as well as the constraints faced at the time of implementation the scholarship. Repetitively, the collected data were then used in the system analysis and design, prototyping, and the testing stages. The participants were also involved in the testing stage, in order to fulfil the system requirements.

\section{RESUlTS AND DisCUSSION}

\section{A. Calculation of TOPSIS}

- Criteria and Weighted

To solve the problem of the scholarship grantee selection using TOPSIS is described as follow:

Phase I: Collect data alternative that will be selected and the used criteria. There were seven criteria that serve as the basis for decision making, i.e.:

$\mathrm{C}_{1}=$ Value of Parents Income
$\mathrm{C}_{2}=$ Dependant number of Parents

$\mathrm{C}_{3}=$ Status of Parents living's

$\mathrm{C}_{4}=\mathrm{GPA}$

$\mathrm{C}_{5}=$ Grade on Religious Subject Knowledge

$\mathrm{C}_{6}=$ Grade on General Subject Knowledge

$\mathrm{C}_{7}=$ Grade on BAZIS Subject Knowledge

Phase II: Data criteria were transformed into crisp form, based on the scores from each criterion shown in the table below:

TABLE 1

CRITERIA FOR AMOUNT OF PARENTS INCOME

\begin{tabular}{cc}
\hline Amount of Parents Income & Crisp Score \\
\hline <Rp. 1 Milion & 1 \\
Rp. 1 Milion - Rp. 1.9 Milion & 2 \\
Rp. 2 Milion - Rp. 2.9 Milion & 3 \\
Rp. 3 Milion - Rp. 3.9 Milion & 4 \\
Rp. 4 Milion & 5
\end{tabular}

TABLE 2

CRiteria For Number of DePENDENTS OF PARENTS

\begin{tabular}{|c|c|}
\hline Number of parents dependents & Crisp Score \\
\hline 1 Child & 1 \\
2 Child & 2 \\
3 Child & 3 \\
4 Child & 4 \\
$\geq 5$ Child & 5 \\
\hline
\end{tabular}

TABLE 3

CRiteria for Status of Living PARENTS

\begin{tabular}{|c|c|}
\hline Status of living parents & Crisp Score \\
\hline Orphan & 1 \\
Fatherless & 2 \\
Motherless & 3 \\
Divorce & 4 \\
Complete & 5 \\
\hline
\end{tabular}

TABLE 4

CRITERIA FOR GPA

\begin{tabular}{|c|c|}
\hline GPA & Crisp Score \\
\hline$<2.00$ & 1 \\
$2.00-2.49$ & 2 \\
$2.50-2.99$ & 3 \\
$3.00-3.49$ & 4 \\
$\geq 3.50$ & 5 \\
\hline
\end{tabular}

TABLE 5

Criteria for VAlue of Religious KNOWLEdGe

\begin{tabular}{|c|c|}
\hline Value of religious knowledge & Crisp Score \\
\hline Very Bad & 1 \\
Bad & 2 \\
Enough & 3 \\
Good & 4 \\
Very Good & 5 \\
\hline
\end{tabular}

TABLE 6

Criteria for VAlue of General KNOWLEdGE

\begin{tabular}{|c|c|}
\hline Value of general knowledge & Crisp Score \\
\hline Very Bad & 1 \\
Bad & 2 \\
Enough & 3 \\
Good & 4 \\
Very Good & 5 \\
\hline
\end{tabular}


TABLE 7

CRiteria For VAlue of Bazis KnOWLedGe

\begin{tabular}{|c|c|}
\hline Value of BAZIS knowledge & Crisp Score \\
\hline Very Bad & 1 \\
Bad & 2 \\
Enough & 3 \\
Good & 4 \\
Very Good & 5 \\
\hline
\end{tabular}

Phase III: In the case of the scholarship grantee selection using TOPSIS method, criteria need to be identified in advanced, whether it includes the type of benefit or cost criteria. The conflict between benefit and cost criteria would affect the selection of the scholarship grantee. The criteria were included in the category of cost criteria, i.e. the value of parent income, and the status of parent living, while the criteria included in the benefit criteria category i.e., the number of parent's dependant, GPA, grade of religious subject knowledge, general subject knowledge, and also BAZIS subject knowledge.

- The Calculation Process of TOPSIS

Process on the data analysis in this study referred to the completion flow of TOPSIS method. The authors used three data sample of the applicants that can be seen in Table 8 .

TABLE 8

Sample Data of Scholarship ApPlicants

\begin{tabular}{|c|c|c|c|c|c|c|c|}
\hline \multirow{2}{*}{ Alt. (A) } & \multicolumn{7}{|c|}{ Criteria (C) } \\
\cline { 2 - 8 } & $\mathrm{C}_{1}$ & $\mathrm{C}_{2}$ & $\mathrm{C}_{3}$ & $\mathrm{C}_{4}$ & $\mathrm{C}_{5}$ & $\mathrm{C}_{6}$ & $\mathrm{C}_{7}$ \\
\hline Julianti & 2.5 & 3 & Complete & 2.91 & $\begin{array}{c}\text { Very } \\
\text { Good }\end{array}$ & Enough & $\begin{array}{c}\text { Very } \\
\text { Good }\end{array}$ \\
\hline Safitrionani & $\begin{array}{c}1.5 \\
\text { Milion }\end{array}$ & 1 & Fatherless & 3.75 & Good & Enough & Good \\
\hline Yulia & 2 Milion & 2 & Fatherless & 3.44 & Enough & Enough & Good \\
\hline
\end{tabular}

The following the steps for resolving TOPSIS method:

(1) Determine the decision matrix (X), it was formed from the result of data conversion applicant into the crisp score, then the matrix X:

$$
X=\left[\begin{array}{lllllll}
3 & 3 & 5 & 3 & 5 & 3 & 5 \\
2 & 1 & 2 & 5 & 4 & 3 & 4 \\
3 & 2 & 2 & 4 & 3 & 3 & 4
\end{array}\right]
$$

(2) Determine of matrix normalization (R)

Based on the equation (1), then the matrix $\mathrm{R}$ :

$R=\left[\begin{array}{lllllll}0.640 & 0.802 & 0.870 & 0.424 & 0.707 & 0.577 & 0.662 \\ 0.426 & 0.267 & 0.348 & 0.707 & 0.566 & 0.577 & 0.530 \\ 0.640 & 0.535 & 0.348 & 0.566 & 0.424 & 0.577 & 0.530\end{array}\right]$

(3) Determine the normalization of weighted matrix $\mathrm{R}$ (Y), matrix $\mathrm{Y}$ was calculated based on the equation (2), it was known that the weight of each criterion (W) $=[5 ; 5 ; 5 ; 4 ; 3 ; 3 ; 3]$, then the matrix Y:

$Y=\left[\begin{array}{lllllll}3.198 & 4.009 & 4.352 & 1.697 & 2.121 & 1.732 & 1.987 \\ 2.132 & 1.336 & 1.741 & 2.828 & 1.697 & 1.732 & 1.589 \\ 3.198 & 2.673 & 1.741 & 2.263 & 1.273 & 1.732 & 1.589\end{array}\right]$

(4) Determine the positive ideal solution $\left(\mathrm{A}^{+}\right)$and negative ideal solution $\left(\mathrm{A}^{-}\right)$, positive ideal solution $\left(\mathrm{A}^{+}\right)$was calculated based on the equation (3), and negative ideal solutions $\left(\mathrm{A}^{-}\right)$were calculated based on the equation (4), then:

Positive Ideal Solution:

$$
\begin{aligned}
& y_{1}^{+}=\min \{3.198 ; 2.132 ; 3.198\}=2.132 \\
& y_{2}^{+}=\max \{4.009 ; 1.336 ; 2.673\}=4.009 \\
& y_{3}^{+}=\min \{4.352 ; 1.741 ; 1.741\}=1.741 \\
& y_{4}^{+}=\max \{1.697 ; 2.828 ; 2.263\}=2.828 \\
& y_{5}^{+}=\max \{2.121 ; 1.697 ; 1.273\}=2.121 \\
& y_{6}^{+}=\max \{1.732 ; 1.732 ; 1.732\}=1.732 \\
& y_{7}^{+}=\max \{1.987 ; 1.589 ; 1.589\}=1.987
\end{aligned}
$$

Negative Ideal Solutions:

$$
\begin{aligned}
& y_{1}^{-}=\max \{3.198 ; 2.132 ; 3.198\}=3.198 \\
& y_{2}^{-}=\min \{4.009 ; 1.336 ; 2.673\}=1.336 \\
& y_{3}^{-}=\max \{4.352 ; 1.741 ; 1.741\}=4.352 \\
& y_{4}^{-}=\min \{1.697 ; 2.828 ; 2.263\}=1.697 \\
& y_{5}^{-}=\min \{2.121 ; 1.697 ; 1.273\}=1.273 \\
& y_{6}^{-}=\min \{1.732 ; 1.732 ; 1.732\}=1.732 \\
& y_{7}^{-}=\min \{1.987 ; 1.589 ; 1.589\}=1.589
\end{aligned}
$$

(5) Determine the distance each alternative to $\mathrm{A}^{+}$and $\mathrm{A}^{-}$, The distance of each alternative to $\mathrm{A}^{+}$was calculated based on the equation (5), and the distance of each alternative to $\mathrm{A}^{-}$calculated based on the equation (6), the results can be seen in Table 9:

TABLE 9

Distance of EACH Alternativesto A ${ }^{+}$AND A

\begin{tabular}{|c|c|c|}
\hline Alternative & $\mathrm{D}^{+}$ & $\mathrm{D}^{-}$ \\
\hline $\mathrm{A}_{1}$ & 3.039 & 2.832 \\
\hline $\mathrm{A}_{2}$ & 2.735 & 3.068 \\
\hline $\mathrm{A}_{3}$ & 2.030 & 2.987 \\
\hline
\end{tabular}

(6) Determine the value of preference for each alternative (V), the proximity of each alternative against the ideal solution was calculated by equation (7), the result of ranking can be seen in Table 10:

TABLE 10

Valueof Preference Each Alternative

\begin{tabular}{|l|c|c|}
\hline Alternative $(\mathrm{A})$ & $\mathrm{V}$ & Rank \\
\hline Yulia $\left(\mathrm{A}_{3}\right)$ & 0.595 & 1 \\
\hline Safitriyani $\left(\mathrm{A}_{2}\right)$ & 0.529 & 2 \\
\hline Julianti $\left(\mathrm{A}_{1}\right)$ & 0.482 & 3 \\
\hline
\end{tabular}

\section{CONCLUSION}

There are seven 7 criteria which can be applied in this study, i.e., income value of the parents, number of parents/dependants, property owned status, GPA, grade of religion subject knowledge, grade of general subject knowledge, and the grade of BAZIS subject knowledge that 
can be applied in TOPSIS method as selection tools. The results of TOPSIS method is to show the applicant ranks based on the weighting calculation before by using determined criteria. Besides the criteria above-mentioned, the study has also conducted within its procedure, data, application development method, and tools. Thus, the use of the different procedure, data, criteria, application development method, and tools may produce the different results. The results of this study may be one of the practical and methodological consideration points for the further similar studies.

\section{REFERENCES}

[1] MNE: 'Strategic Planning 2010-2014', in Editor (Ed.) ${ }^{\wedge}(E d s$.$) : 'Book$ Strategic Planning 2010-2014' (Ministry of National Education (MNE), 2010, edn.), pp.

[2] Bonczek, R.H., Holsapple, C.W., and Whinston, A.B.: 'Foundations of decision support systems' (Academic Press, 2014. 2014)

[3] $\mathrm{Xu}, \mathrm{Z} .:$ 'Uncertain multi-attribute decision making: Methods and applications' (Springer, 2015. 2015)

[4] Zhang, L.: 'Multi-attribute Decision Making': 'Encyclopedia of Quality of Life and Well-Being Research' (Springer, 2014), pp. 4164-4166

[5] Joshi, D., and Kumar, S.: 'Interval-valued intuitionistic hesitant fuzzy Choquet integral based TOPSIS method for multi-criteria group decision making', European Journal of Operational Research, 2016, 248, (1), pp. 183-191

[6] Liaudanskienè, R., Ustinovičius, L., and Bogdanovičius, A.: 'Evaluation of construction process safety solutions using the TOPSIS method', Engineering Economics, 2015, 64, (4)

[7] Aly, M.F., Attia, H.A., and Mohammed, A.M.: 'Integrated fuzzy (GMM)-TOPSIS model for best design concept and material selection process', International Journal of Innovative Research in Science, Engineering and Technology, 2013, 2, (11), pp. 6464-6486

[8] Eraslan, S.: 'A decision-making method via TOPSIS on soft sets', Journal of New results in Science, 2015, 8, (8)

[9] Kusumadewi, S., Hartati, S., Harjoko, A., and Wardoyo, R.: 'Fuzzy Multi-Attribute Decision Making (Fuzzy MADM)', Yogyakarta: Graha Ilmu, 2006

[10] Saragih, H., Marbun, M., and Reza, B.: 'Development of Decision Support System Determining the Student as Scholarship Recipients by Fuzzy Multi Attribute Decision Making (FMADM)', Jurnal Sistem Informasi, 2014, 9, (2), pp. 75-81

[11] Wimatsari, G., Putra, K., and Buana, P.W.: 'Multi-attribute decision making scholarship selection using a modified fuzzy TOPSIS', International Journal of Computer Sciences, 2013, 10, (2), pp. 309-317

[12] Srikrishan, S., Sreenivasulu Reddy, A., and Vani, S.: 'A New Car Selection in the Market using TOPSIS Technique', International Journal of Engineering Research and General Science, 2014, 2

[13] Stair, R., and Reynolds, G.: 'Fundamentals of information systems' (Cengage Learning, 2012. 2012)

[14] Mingers, J., Mutch, A., and Willcocks, L.: 'Introduction [special issue: Critical realism in information systems research]', MIS quarterly, 2013, 37, (3), pp. 795-802

[15 Subiyakto, A., Ahlan, A.R., and Sukmana, H.T.: 'An Alternative Method for Determining Critical Success Factors of Information System Project', TELKOMNIKA Telecommunication, Computing, Electronics and Control, 2014, 12, (3), pp. 665-674

[16] Subiyakto, A., and Ahlan, A.R.: 'Implementation of Input-ProcessOutput Model for Measuring Information System Project Success', TELKOMNIKA Indonesian Journal of Electrical Engineering, 2014, 12, (7), pp. 5603-5612

[17] Subiyakto, A.a., Ahlan, A.R., Putra, S.J., and Kartiwi, M.: 'Validation of Information System Project Success Model', SAGE Open, 2015, 5, (2), pp. 1-14 